\title{
Latent heat loss of Holstein cows in a tropical environment: a prediction model
}

\author{
Alex Sandro Campos Maia ${ }^{1}$, Roberto Gomes da Silva ${ }^{2}$, Cintia Maria Battiston Loureiro ${ }^{3}$ \\ ${ }^{1}$ Laboratório de Biometeorologia e Bem-Estar Animal, Departamento de Ciências Animais da Universidade Federal Rural do Semi-Árido, \\ Mossoró, RN, Brasil. \\ 2 Departamento de Zootecnia, Faculdade de Ciências Agrárias e Veterinária, Universidade Estadual Paulista, Campus de Jaboticabal, \\ Jaboticabal, SP, Brasil. \\ 3 Programa de Pós-graduação em Zootecnia, Faculdade de Ciências Agrárias e Veterinária, Universidade Estadual Paulista, Campus de \\ Jaboticabal, Jaboticabal, SP, Brasil.
}

\begin{abstract}
Nine lactating Holstein cows with average $526 \pm 5 \mathrm{~kg}$ of BW, five predominantly black and four predominantly white, bred in a tropical region and managed in open pasture were observed to measure cutaneous and respiratory evaporation rates under different environmental conditions. Cows were separated in three weight class: 1 ( $\leq 450 \mathrm{~kg}), 2$ (450-500 kg) and 3 (>500 kg). Latent heat loss from cutaneous surface was measured using a ventilated capsule; evaporation in the respiratory system was measured using a facial mask. The results showed that heaviest cows ( 2 and 3 classes) presented the least evaporation rates. When air temperature increased from 10 to $36^{\circ} \mathrm{C}$ the relative humidity decreased from 90 to $30 \%$. In these conditions the heat loss by respiratory evaporation increased from 5 to $57 \mathrm{Wm}^{-2}$, while the heat loss by cutaneous evaporation increased from 30 to $350 \mathrm{Wm}^{-2}$. The results confirm that latent heat loss was the main way of thermal energy elimination under high air temperatures $\left(>30^{\circ} \mathrm{C}\right)$; cutaneous evaporation was the main mechanism of heat loss, responding for about $85 \%$ of the heat loss. A model was presented for the prediction of the latent heat loss that was based on physiological and environmental variables and could be used to estimate the contribution of evaporation to thermoregulation; a second, based on air temperature only, should be used to make a simple characterization of the evaporation process.
\end{abstract}

Key Words: evaporation rate, Holstein cows, tropical environment

\section{Perda de calor latente em vacas Holandesas em ambiente tropical: um modelo de predição}

RESUMO - Nove vacas Holandesas lactantes com $526 \pm 5 \mathrm{~kg}$ de peso corporal (cinco predominantemente pretas e quatro predominantemente brancas), criadas em região tropical e manejadas em pastagens, foram observadas com os objetivos de determinar simultaneamente as taxas de evaporação cutânea e respiratória em ambiente tropical e desenvolver modelos de predição. Para a medição da perda de calor latente pela superfície corporal, utilizou-se uma cápsula ventilada e, para a perda por respiração, utilizou-se uma máscara facial. Os resultados mostraram que as vacas que tinham maior peso corporal (classe 2 e 3) apresentaram maiores taxas evaporativas. Quando a temperatura do ar aumentou de 10 para $36^{\circ} \mathrm{C}$ e a umidade relativa do ar caiu de 90 para 30\%, a eliminação de calor por evaporação respiratória aumentou de aproximadamente 5 para $57 \mathrm{~W} \mathrm{~m}^{-2}$ e a evaporação na superfície corporal passou de 30 para $350 \mathrm{~W} \mathrm{~m}^{-2}$. Esses resultados confirmam que a eliminação de calor latente é o principal mecanismo de perda de energia térmica sob altas temperaturas $\left(>30^{\circ} \mathrm{C}\right)$; a evaporação cutânea é a maior via e corresponde a aproximadamente $85 \%$ da perda total de calor, enquanto o restante é eliminado pelo sistema respiratório. O modelo para predizer o fluxo de perda de calor latente baseado em variáveis fisiológicas e ambientais pode ser utilizado para estimar a contribuição da evaporação na termorregulação, enquanto o modelo baseado somente na temperatura do ar deve ser usado apenas para a simples caracterização do processo evaporativo.

Palavras-chave: ambiente tropical, taxa de evaporação, vacas Holandesas

\section{Introduction}

Thermal equilibrium is achieved by cattle when the amount of heat produced by metabolic reactions equals the heat gained by the body from the environment. However, under too high environmental temperatures the thermal equilibrium can hardly be attained and in these circumstances the heat excess can be stored in the body tissues (Finch, 1985; McLean et al., 1983), thus increasing body temperature.

Under low ambient temperatures thermal energy is lost mainly as sensible heat due to the large temperature 
difference between the body surface and the environment (McLean 1963). In contrast, under high temperatures the body can gain heat by convection (Gebremedhin \& Binxin, 2001); if the environment is characterized by intense solar radiation the body gains large amounts of heat by radiation (Curtis, 1982). In those conditions the ability of the animal to withstand its environment is proportional to its ability to dissipate heat by evaporation from the skin surface as a result of sweating (Finch et al., 1982; McLean, 1963; Maia et al., 2005a) or from the respiratory system by panting (Stevens 1981; Maia et al., 2005b).

Knowledge about the latent heat flow from Holstein cows managed under natural conditions in a tropical environment would contribute to genetic improvement programmes of dairy cattle in the tropics, by including fitness characteristics that are more favourable to the heat balance of animals. In addition, knowledge about latent heat loss mechanisms can be used to develop mathematical and physical models as those proposed by Stevens (1981), McLean (1963), Gebremedhin et al. (1981), Turnpenny et al. (2000) and McGovern \& Bruce (2000) to explain thermal interaction between livestock and their environment.

These models have become valuable tools to determine how climatic events, mainly due to the improvement of shelter and management practices, affect the animal. The present investigation aims to measure the latent heat loss from the body surface and from the respiratory tract of Holstein cows managed under natural conditions in a tropical environment, with the objective of establish predicting models based on simple physiological and environmental measurements.

\section{Material and Methods}

Nine lactating Holstein cows were used, five predominantly black and four predominantly white, with average $526 \pm 5 \mathrm{~kg}$ pf BW. Cows were separated in three weight class: $1(\leq 450 \mathrm{~kg}), 2(450-500 \mathrm{~kg})$ and $3(>500 \mathrm{~kg})$. The cows were observed under the environmental conditions of $\left(21^{\circ} 15^{\prime} 22^{\prime \prime}\right.$ South, 48 $18^{\prime} 58^{\prime \prime}$ West, $595 \mathrm{~m}$ altitude) during the period of July-September 2004. The observations were made 1 or 2 days per week in the time period from 01:00 a.m. to 06:00 p.m. The cows were managed in open pasture and received silage ad libitum twice a day, always after milking (05:00 a.m. and 01:00 p.m. respectively). Their average milk yield was $15 \mathrm{~kg}$ per day. The animals were observed after milking inside the milk parlour, where one cow at a time was kept standing inside an enclosure $(1.2 \mathrm{x}$ $3.0 \mathrm{~m}$ ), while the other cows remained outside the milking parlour in a pen where they were exposed to direct sunlight.
Black globe, dry and wet-bulb temperatures and air velocity were taken near the animals inside the milking parlour (approximately $1.0 \mathrm{~m}$ from each animal, $3.5 \mathrm{~m}$ from the roof and $1.0 \mathrm{~m}$ from the floor).

Dry and wet-bulb temperatures were measured with a portable sling psychrometer; air velocity was determined by a thermo-anemometer (Alnor APM-360); for the blackglobe temperature there was used a standard $0.15 \mathrm{~m}$ diameter hollow copper painted matt black. The black-globe temperature was used to estimate the mean radiant temperature $\left(T_{R M}, \mathrm{~K}\right)$ according to DaSilva (2000). All these recordings were made as each cow was sampled.

The latent heat flow from the respiratory system and that from the cutaneous surface were determined at the same time, by using a facial mask and a ventilated capsule respectively. The heat loss by respiratory evaporation

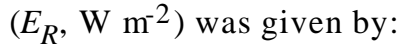

$E_{R}=\frac{\lambda V F\left(\Psi_{E}-\Psi_{A}\right)}{60 \mathrm{~A}}$

while the heat loss by cutaneous evaporation $\left(E_{S}, \mathrm{~W} \mathrm{~m}^{-2}\right)$ was given by:

$E_{S}=\frac{\lambda f_{c}\left(\Psi_{C}-\Psi_{A}\right)}{A_{C}}$

where $\lambda=2500.7879-2.3737 t_{A}$ is the latent heat of vaporisation $\left(\mathrm{Jg}^{-1}\right), A$ is the body surface area $\left(A=0.13 w^{0.556}, \mathrm{~m}^{2}\right)$, $w$ is the body weight $(\mathrm{kg}), A_{C}$ the area of skin covered by the capsule $\left(0.00724 \mathrm{~m}^{2}\right)$ and $\Psi_{\mathrm{A}}, \Psi_{\mathrm{E}}$ e $\Psi_{\mathrm{C}}\left(\mathrm{g} \mathrm{m}^{-3}\right)$ are absolute air humidity of the atmosphere, of the expired air and of the air outgoing the capsule; they are given respectively by:

$$
\begin{aligned}
& \Psi_{A}=\frac{2166.87 \mathrm{P}_{\mathrm{P}}\left\{\mathrm{t}_{\mathrm{A}}\right\}}{273.15+t_{A}} \\
& \Psi_{E}=\frac{2166.87 \mathrm{P}_{\mathrm{P}}\left\{\mathrm{t}_{\mathrm{E}}\right\}}{273.15+t_{E}} \\
& \Psi_{C}=\frac{2166.87 \mathrm{P}_{\mathrm{P}}\left\{\mathrm{t}_{\mathrm{C}}\right\}}{273.15+t_{C}}
\end{aligned}
$$

where $\mathrm{P}_{\mathrm{P}}\left\{\mathrm{t}_{A}\right\}, \mathrm{P}_{\mathrm{P}}\left\{\mathrm{t}_{E}\right\}$ and $\mathrm{P}_{\mathrm{P}}\left\{\mathrm{t}_{C}\right\}$ are the partial vapour pressures $(\mathrm{kPa})$ of the air ambient, air expired and air from the capsule, respectively; $t_{A}, t_{E}$ and $t_{C}$ are the temperatures (Celsius degree) of atmosphere, expired air and the air from the capsule respectively. $\mathrm{A} \mathrm{CO}_{2} / \mathrm{H}_{2} \mathrm{O}$ gas analyzer (Li-Cor, mod. LI-6262) was connected by tubing to the mask's outlet valve and to the capsule outlet tube, in order to determine $\Psi_{\mathrm{E}}$ and $\Psi_{\mathrm{C}}$.

Air flow rate $\left(f_{C}, \mathrm{~m}^{3} \mathrm{~s}^{-1}\right)$ over the hair coat surface within the capsule was obtained by multiplying the cross-section 
area $\left(0.0003630 \mathrm{~m}^{2}\right)$ at the air outlet tube of the capsule by the velocity $\left(U_{C}, \mathrm{~m} \mathrm{~s}^{-1}\right)$ of the air passing over the hair coat surface; $U_{C}$ was measured by a precision thermoanemometer (Alnor APM-360) set at the air outlet tube of the capsule (for more details see Maia et al., 2005a). Tidal volume $\left(V, \mathrm{~m}^{3}\right.$ breath $\left.^{-1}\right)$ was determined as follows: the probe of a precision thermo-anemometer (Alnor APM-360) was set at the mask air inlet, in order to measure the speed of the air entering the mask during the respiration process; as the inspiration-expiration wave was known to be approximately a square wave, the air speed measured as above described was assumed to be the mean air velocity, $U_{M}\left(\mathrm{~m} . \mathrm{s}^{-1}\right)$. The radius $(r)$ of the air inlet was $0.023 \mathrm{~m}$, the volume of air entering the mask was $\pi \mathrm{r}^{2} U_{M}=0.0016619 U_{M}$ $\mathrm{m}^{3} \mathrm{~s}^{-1}$, thus the tidal volume can be given by:

$V=0.0997141 U F^{-1}$

where $F$ is the respiratory rate (breaths $\min ^{-1}$ ). It was determined by counting the movements of the air inlet valve of the mask (for more details see Maia et al., 2005b). The total heat flux by evaporation $\left(E_{T}, \mathrm{~W} \mathrm{~m}^{-2}\right)$ was $E_{T}=E_{R}+E_{C}$.

Data were initially analysed by the least-squares method (Harvey 1960) using the Statistical Analysis System (SAS, 2001), according to Littell et al., (1991). The statistical model used to describe the total heat loss by evaporation was:

$Y_{i j k l}=\alpha+w_{i}+r_{j}+c_{i k}+b_{1} t_{A}+b_{2} t_{A}^{2}+b_{3} U_{R}+b_{4} U_{R}^{2}+\varepsilon_{i j k l}$

where $Y_{i j k l}$ is the total heat loss by evaporation $\left(E_{T}\right)$ in the $l$ th cow; $w_{i}$ is the fixed effect of the $i$ th weight class $(i=1, \ldots, 3) ; r_{j}$ is the fixed effect of the $j$ th repetition $(j=1, \ldots, 9)$; $c_{j k}$ is the random effect of the $k$ th cow within weight class $(k=1, \ldots, 3$ for $i=1 ; k=1, \ldots, 3$ for $i=2 ; k=1, \ldots, 3$ for $i=3)$; $\mathrm{b}_{1}, \mathrm{~b}_{2}, \mathrm{~b}_{3}$ and $\mathrm{b}_{4}$ are the linear and quadratic regression coefficients on air temperature and air relative humidity; $\varepsilon_{i j k 1}$ is the residual term, inclusive the random error; and $\alpha$ is the intercept.

Non-linear regression methods were used to estimate $E_{R}, E_{C}, E_{T}$ and $t_{C}$, as function of air temperature and humidity, using Origin-5 software (Microcal Software Inc., Northampton, Mass. USA).

\section{Results and Discussion}

Heaviest cows ( 2 and 3 classes) presented the least evaporation rates (Table 1). In fact, lighter animals have larger body surface areas in relation to the volume. Cutaneous evaporation losses increase as the environmental
Table 1 - Total evaporative heat loss in Holstein cows, according to the body weight

\begin{tabular}{lc}
\hline Item & Total latent heat loss $\left(\mathrm{W} \mathrm{m}^{-2}\right)$ \\
\hline Overall mean & $72.54 \pm 9.87$ \\
Weight class & $123.01 \pm 9.22 \mathrm{a}$ \\
$1(\leq 450 \mathrm{~kg})$ & $98.70 \pm 8.70 \mathrm{~b}$ \\
$2(450-500 \mathrm{~kg})$ & $96.11 \pm 7.14 \mathrm{~b}$ \\
$3(>500 \mathrm{~kg})$ & \\
\hline
\end{tabular}

Means within a column with different superscript differ $(P<0.05)$ by Tukey test.

temperature rises (especially above $24^{\circ} \mathrm{C}$ ), becoming the main way of latent heat dissipation (Figure 1). In such a condition the larger relative surface area of class 1 cows would certainly favours a greater potential for total heat flow by evaporation.

Latent heat loss (Figure 1) increases with air temperature in almost a linear fashion until $25^{\circ} \mathrm{C}$ and then becomes increasingly high as the ambient temperature rises above $27^{\circ} \mathrm{C}$. The same was observed by Finch (1985) and Kibler \& Brody (1954). This increase in the evaporative heat loss was presumably a direct consequence of the decreased thermal gradient between the coat surface temperature and that of the surrounding air. When $t_{A}$ was $10^{\circ} \mathrm{C}, t_{C}$ was about $27^{\circ} \mathrm{C}$; but when $t_{A}$ reaches $35^{\circ} \mathrm{C}$, $t_{C}$ increases to near $37^{\circ} \mathrm{C}$ (Figure 1 and 2 ). Consequently the thermal gradient decreases from $17^{\circ} \mathrm{C}$ to only $2^{\circ} \mathrm{C}$, thus weakening the convection heat flux and causing the thermal radiation exchange to become a way of heat gain (Maia et al., 2005a; Gebremedhin \& Binxin, 2001).

Total heat flux by evaporation (Figure 1) averaged $17.40 \pm 0.92 \mathrm{Wm}^{-2}$ when the air temperature was $>20^{\circ} \mathrm{C}$ and the air humidity approached $80 \%$; from this total, an amount of $4.66 \pm 0.34 \mathrm{Wm}^{-2}$ was lost in the respiratory tract and $12.81 \pm 0.99 \mathrm{Wm}^{-2}$ through the cutaneous surface. These values agree with those found by Kibler \& Brody (1954). However, when the air temperature reached $35^{\circ} \mathrm{C}$ and the air humidity decreased to $<30 \%$ the total evaporation was $264.67 \pm 37 \mathrm{Wm}^{-2}$ on the average, being $216.88 \pm 33 \mathrm{Wm}^{-2}$ lost by cutaneous evaporation while the rest was lost by respiratory evaporation.

Heat loss by evaporation was highly correlated with air relative humidity and this correlation was negative, while the contrary was observed for the air temperature (Figure 3 ). On the other hand, there was a high correlation between air relative humidity and air temperature, near 0.86 ; therefore, during the realization of the present study there were occurred low levels of air relative humidity in association to high environmental temperatures; a fact to be expected, 


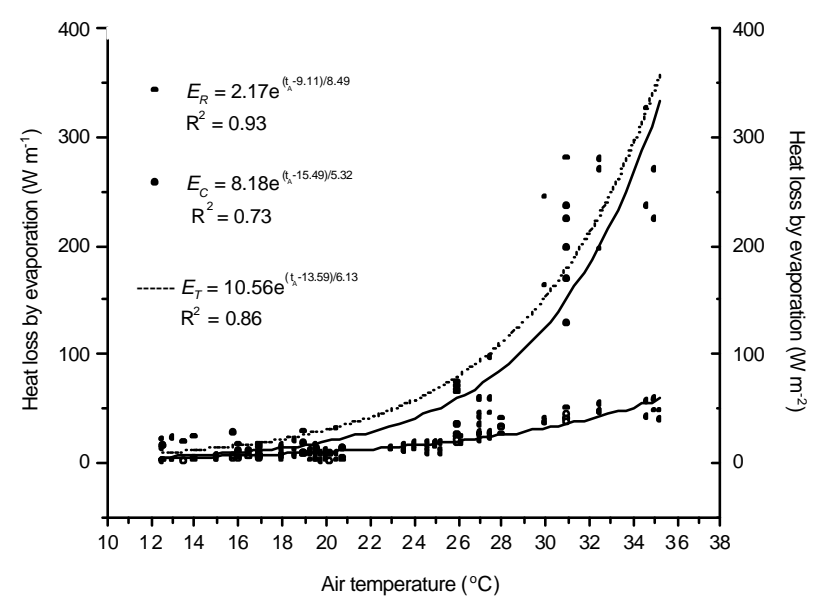

Figure 1 - Heat loss flux by respiratory $\left(E_{R} ; 0\right)$ and cutaneous $\left(E_{C} ; \bullet\right)$ evaporation of Holstein cows as functions of the air temperature. $E_{T}=E_{R^{+}} E_{C}$

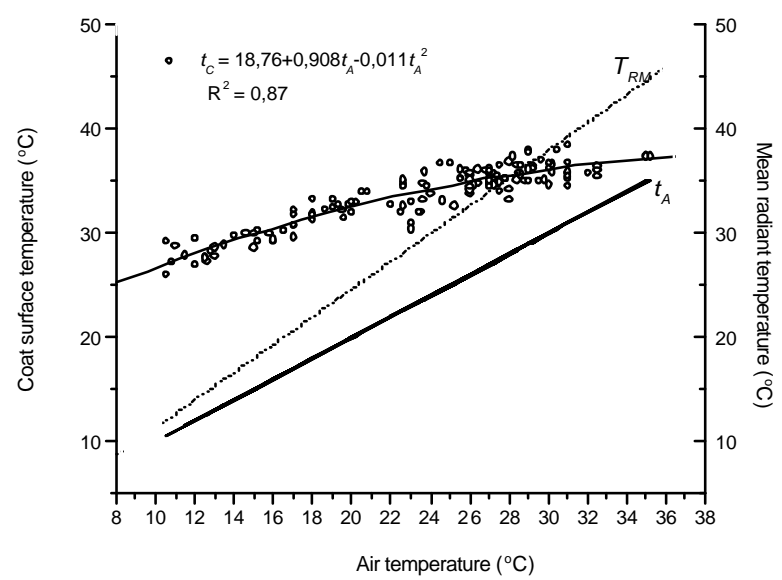

Figure 2 - Coat surface temperature $\left(t_{C} ; 0\right)$ of Holstein cows as function of air temperature $\left(-t_{A}\right)$.

as in most Brazilian country the summer was the rainy season. Such a correlation could explain why the inclusion of the air relative humidity in the prediction model for evaporative heat loss did not markedly increase the $\mathrm{R}^{2}$ value.

Two models were used to predict the total heat flux by evaporation. Model 1 was based on the linear function of $t_{A}$ given by $\log E T=\left(0.86+t_{A}\right) 613^{-1}$. For example, a Holstein cow observed under $35^{\circ} \mathrm{C}$ air temperature dissipated about $347.2 \mathrm{Wm}^{-2}$ of latent heat, as estimated by this model.

In the model 2 the total heat flux by evaporation can be described by Figure 4.

In Figure $4, \Psi_{A}$ e $\Psi_{E}$ were combines in the operative humidity $\Psi_{O}\left(\mathrm{~g} \mathrm{~m}^{-3}\right)$, thus:

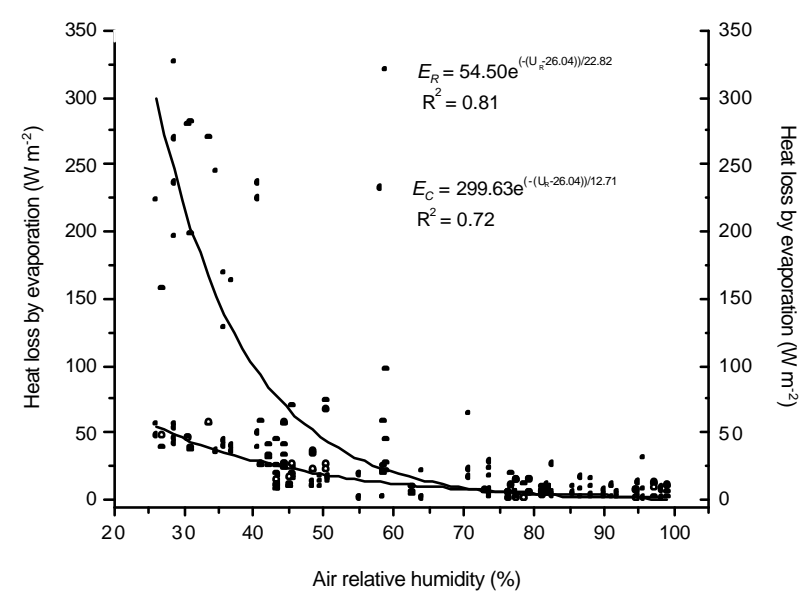

Figure 3 - Heat loss flux by respiratory $\left(E_{R} ; 0\right)$ and cutaneous $\left(E_{C} ; \bullet\right)$ evaporation of Holstein cows as functions of the air relative humidity.

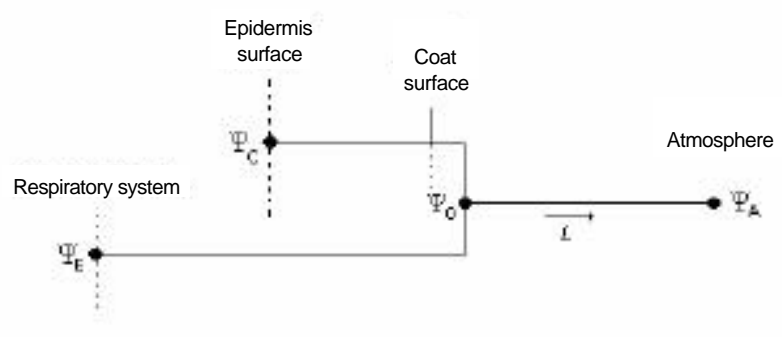

Figure 4 - Heat total flow by evaporation between animal and environment. $\Psi_{A}, \Psi_{E}, \Psi_{S}$ are the absolute humidity of atmosphere, expired air, and cutaneous surface; $\Psi_{\mathrm{O}}$ was the operative absolute humidity.

$\frac{\lambda V F\left(\Psi_{O}-\Psi_{A}\right)}{60 A}+\frac{\lambda f_{C}\left(\Psi_{O}-\Psi_{A}\right)}{A_{C}}=\frac{\lambda V F\left(\Psi_{E}-\Psi_{A}\right)}{60 A}+\frac{\lambda f_{C}\left(\Psi_{C}-\Psi_{A}\right)}{A_{C}}$

and solving for $\Psi_{O}\left(\mathrm{~g} \mathrm{~m}^{-3}\right)$ the result was:

$\Psi_{O}=\frac{60 A f_{C} \Psi_{C}+A_{C} V F \Psi_{E}}{60 A f_{C}+A_{C} V F}$

knowing that $\mathrm{A}_{C}=0.00724 \mathrm{~m}^{2}$; the air flow rate through the capsule $\left(f_{C}\right)$ was set at $1.74-2.05 \mathrm{~L} \mathrm{~min}^{-1}$, considering the mean value to $f_{C}=1.90 \mathrm{~L} \mathrm{~min}^{-1}$ or $3.17 \times 10-5 \mathrm{~m}^{3} \mathrm{~s}^{-1}$. Thus

$\Psi_{O}=\frac{114 A \Psi_{C}+0.00724 V F \Psi_{E}}{114 A+0.00724 V F}$

There $\Psi_{O}$ depends on $\Psi_{E}$ and $\Psi_{C}$ that are given by equations 5 and 6 respectively and that depends on $\mathrm{P}_{\mathrm{P}}\left\{\mathrm{t}_{\mathrm{C}}\right\} ; t_{E}$ was estimated according to Maia et al. (2005b) and Maia (2005), as:

$t_{E}=9.47+t_{A}\left(1.18-0.01278 t_{A}\right)$ 
$P_{P}\left\{t_{C}\right\}=-25.40-0.896 t_{A}+2.17 t_{C}-0.0096 t_{A}^{2}-0.046 t_{S}^{2}+0.043 t_{A} t_{S}$ [12]

while $V$ was estimated from the respiration rate, according to Maia et al. (2005b) by:

$V=\frac{F-2}{-755.32+161.93(F-2)+1.97(F-2)^{2}}$

Together with the equations $5,6,11$ and $13, \Psi_{O}$ was estimated in function of $t_{A}, t_{C}, F$ and body weight, without the use of facial mask and ventilated capsule. Thus

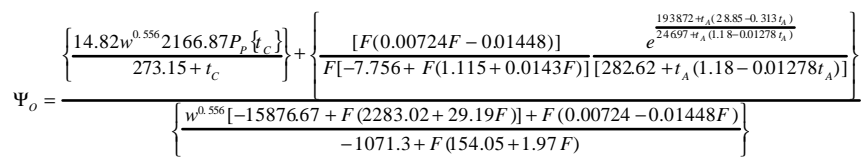

[14]

Finally, the total latent heat flow from animal $\left(E_{T}, \mathrm{~W} \mathrm{~m}^{-2}\right)$ was given by:

$E_{T}=\frac{\left[\lambda\left(\Psi_{O}-\Psi_{A}\right)\left(60 A f_{C}+A_{C} V F\right)\right]}{60 A A_{C}}$

$E_{T}=\frac{\lambda\left(\Psi_{o}-\Psi_{A}\right)\left\{w^{0.556}[-0.2646+F(0.038+0.000486 F)]+F(0.00724 F-0.01448)\right\}}{0.0565 w^{0.55}[-1071.3+F(154.05+1.97 F)]}$

[16]

In order to test the model, we can consider a $570 \mathrm{~kg}$

Holstein cow standing inside the milk parlour under $35^{\circ} \mathrm{C}$ air temperature and $1.60 \mathrm{kPa}$ partial pressure. The cow has a respiratory rate of 57 breaths per minute and a coat surface temperature of $37^{\circ} \mathrm{C}$. In this environmental condition the latent heat of vaporisation was $\lambda=2417.71 \mathrm{Jg}^{-1}$. We can calculate:

$P_{P}\left\{t_{C}\right\}=-25.40-0.896(35)+2.17(37)-0.0096\left(35^{2}\right)-0.046\left(37^{2}\right)+0.043(35)(37)$ $=4.47 \mathrm{kPa}$

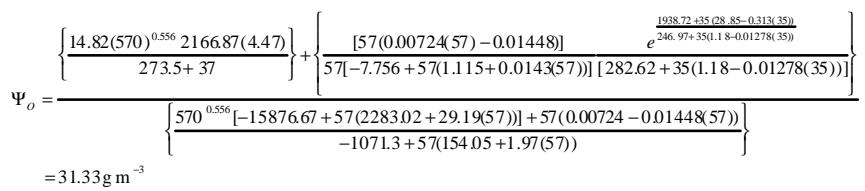

$\Psi_{A}=\frac{2166.87(1.60)}{273.15+35}=11.25 \mathrm{~g} \mathrm{~m}^{-3}$

$E_{T}=\frac{2417.71(31.33-11.25)\left\{570^{0.556}[-0.2646+57(0.038+0.000486(57))]+57(0.00724(57)-0.01448)\right\}}{0.05659(570)^{0.556}[-1071.3+57(154.05+1.97(57))]}$ $=252.77 \mathrm{~W} \mathrm{~m}^{-2}$

Therefore, in the specified conditions the contribution of the latent heat to the cow's thermoregulation was $252.77 \mathrm{~W} \mathrm{~m}^{-2}$, as based in model 2 .

For test power prediction of these models was comparing simulated $\left(E_{S 1}\right.$ and $\left.E_{S 2}\right)$ and measured $\left(E_{M}\right)$ values using mean squared deviation ( $M S D)$ and its components, according to Kobayashi \& Salam (2000):

$M S D=\frac{1}{n} \sum_{i=1}^{n}\left(E_{S_{i}}-E_{M_{i}}\right)=S B+S D S D+L C S$ [17]

Table 2 - Total evaporation $\left(E_{T}\right)$ in a Holstein cow measured with facial mask and ventilated capsule and values of evaporation simulated by model $1\left(E_{S 1}\right)$ and model $2\left(E_{S 2}\right)$

\begin{tabular}{|c|c|c|c|c|c|c|c|c|}
\hline Item & ${ }^{1}$ Fbreath. $\min ^{-1}$ & ${ }^{2} \mathrm{t}_{\mathrm{A}}{ }^{\circ} \mathrm{C}$ & ${ }^{3} \mathrm{t}_{\mathrm{U}^{\circ}}{ }^{\circ} \mathrm{C}$ & ${ }^{4} t_{S}{ }^{\circ} \mathrm{C}$ & $5_{\mathrm{wkg}}$ & $\mathrm{EW} \mathrm{m^{-2 }}$ & $\mathrm{E}_{\mathrm{S} 1} \mathrm{~W} \mathrm{~m}^{-2}$ & $\mathrm{E}_{\mathrm{S} 2} \mathrm{~W} \mathrm{~m}^{-2}$ \\
\hline 01 & 15 & 12 & 10.5 & 26.8 & 600 & 18.07 & 8.15 & 15.36 \\
\hline 02 & 21 & 12 & 10.5 & 27.7 & 540 & 44.96 & 8.15 & 29.26 \\
\hline 03 & 22 & 13 & 9.5 & 27.9 & 540 & 51.93 & 9.59 & 56.82 \\
\hline 04 & 21 & 15 & 14.2 & 28.7 & 540 & 24.38 & 13.29 & 22.48 \\
\hline 05 & 17 & 16 & 15 & 30.3 & 570 & 34.89 & 15.65 & 38.32 \\
\hline 06 & 22 & 16 & 15 & 29.4 & 550 & 38.05 & 15.65 & 30.72 \\
\hline 07 & 19 & 17 & 15 & 31.9 & 450 & 38.45 & 18.42 & 57.61 \\
\hline 08 & 26 & 18 & 16 & 32.4 & 590 & 69.11 & 21.68 & 58.97 \\
\hline 09 & 25 & 20 & 19 & 33.0 & 570 & 37.99 & 30.05 & 43.64 \\
\hline 10 & 36 & 20 & 20.0 & 33.0 & 590 & 22.87 & 30.05 & 25.81 \\
\hline 11 & 52 & 21 & 20.2 & 33.9 & 560 & 47.64 & 35.38 & 40.09 \\
\hline 12 & 23 & 23 & 18 & 31.0 & 540 & 51.90 & 49.02 & 73.25 \\
\hline 13 & 55 & 25 & 22 & 32.6 & 590 & 55.91 & 67.94 & 53.30 \\
\hline 14 & 42 & 26 & 22 & 34.5 & 540 & 123.58 & 79.97 & 92.49 \\
\hline 15 & 60 & 26 & 18 & 34.2 & 500 & 183.97 & 79.97 & 171.58 \\
\hline 16 & 56 & 27 & 21 & 35.3 & 500 & 114.96 & 94.15 & 137.67 \\
\hline 17 & 41 & 27 & 21 & 35.2 & 570 & 116.55 & 94.15 & 132.08 \\
\hline 18 & 38 & 27 & 23 & 35.2 & 600 & 114.24 & 94.15 & 90.71 \\
\hline 19 & 30 & 28 & 19 & 33.2 & 500 & 161.60 & 110.83 & 144.23 \\
\hline 20 & 52 & 31 & 21 & 36.9 & 550 & 218.88 & 180.80 & 208.34 \\
\hline 21 & 31 & 32 & 20.0 & 36.2 & 780 & 213.05 & 212.84 & 217.27 \\
\hline 22 & 35 & 35 & 21 & 37.5 & 570 & 270.46 & 347.21 & 257.20 \\
\hline 23 & 56 & 35 & 21 & 38.0 & 600 & 339.97 & 347.21 & 273.59 \\
\hline
\end{tabular}

${ }^{1}$ Respiration rate, ${ }^{2}$ air temperature, ${ }^{3}$ water bulb temperature, ${ }^{4}$ body surface temperature and ${ }^{5}$ weight. 


$$
\begin{aligned}
& S B=\left(\bar{E}_{S_{i}}-\bar{E}_{M_{i}}\right)^{2} \\
& S D S D=\left(S D_{S}-S D_{M}\right)^{2} \\
& L C S=2 S D_{S} S D_{M}(1-r)
\end{aligned}
$$

where $S B$ represent the bias of simulation from measurements, $S D S D$ was the difference in the magnitude of fluctuation between the simulation and measurement, while $L C S$ was the lack of positive correlation weighted by standard deviation, $r$ was the correlation coefficient, $S D_{S}$ and $S D_{M}$ are standard deviation of simulation and measurement values, respectively and are the means of simulation and measurement values, respectively.

The value of $M S D$ for model 2 was smaller than model 1 (Figure 5). The same result occurred for $S B, S D S D$ and mainly for $L C S$. The bigger value of $L C S$ for model 1 indicated that this model failed to simulate the pattern of fluctuation across the $n$ measurements. This fact occurred due its higher $S D_{S}\left(96.63 \mathrm{~W} \mathrm{~m}^{-2}\right)$ than the $S D_{S}\left(77.25 \mathrm{~W} \mathrm{~m}^{-2}\right)$ for model 2. The lower the value of $M S D$ for model 2 showed that the closer the simulation was to the measurement, obliviously indicating that this model was better than the model 1 for predicted value of heat loss by evaporation. This result indicated that the inclusion of physiological variables like respiration rate and body surface temperature in combination with environmental variables as air temperature and air humidity can improve the prediction power of the model.

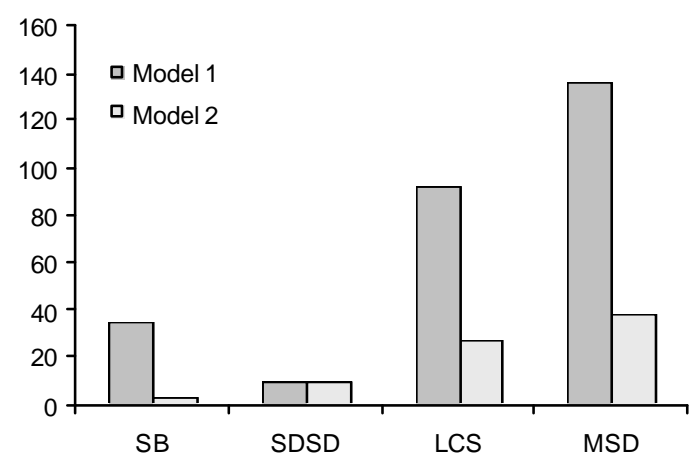

Figure 5 - Comparison of the mean squared deviation (MSD) and its components, lack of correlation weighted by the standard deviation ( $L C S$ ), squared difference between standard deviation (SDSD) and squared bias $(S B)$ for model 1 and 2 . The values must be multiplicity by 100 .

\section{Conclusions}

In Holstein cows managed in tropical environment the dissipation of latent heat by evaporation is the main way of elimination of excess thermal energy, when air temperature exceeds $30^{\circ} \mathrm{C}$. Cutaneous evaporation is responsible by $80 \%$ of total latent heat loss, while the rest is eliminated by respiratory evaporation. The prediction model for latent heat loss based on physiological and environmental variables can be used to estimate the contribution of evaporation for thermoregulation, while the model based on air temperature only must be used solely to make simple characterization of the evaporation process.

\section{Literature Cited}

SILVA, R.G. Introdução à bioclimatologia animal. São Paulo: Nobel, 2000. 285p.

FINCH, V.A. Comparison of non-evaporative heat transfer in different cattle breeds. Australian Journal Agricultural Research, v.36, p.497-508, 1985.

FINCH, V.A.; BENNETT, I.L.; HOLMES, C.R. Sweating response in cattle and its relation to rectal temperature, tolerance of sun and metabolic rate. Journal Agricultural Science, v.99, p.479-487, 1982 .

GEBREMEDHIN, K.G.; CRAMER, C.O.; PORTER, W.P. Predictions and measurements of heat production and food and water requirements of Holstein calves in different environments. Transactions of the ASAE, v.3 p.715-720, 1981.

GEBREMEDHIN, K.G.; BINXIN, W. A model of evaporation cooling of wet skin surface and fur layer. Journal of Thermal Biology, v.26, p.537-545, 2001.

HARVEY, W.R. Least-squares analysis of data with unequal subclass numbers. Beltaville: U.S.D.A., 1960. 157p.

HILLMAN, P.E.; LEE, C.N.; PARKHURST, A. Impact of hair color on thermoregulation of dairy cows to direct sunlight. In: ANNUAL INTERNATIONAL MEETING OF THE ASAE, 94., 2001, Sacramento. Proceedings... Sacramento, 2001. (Paper, 014301).

KIBLER, H.H.; BRODY, S. Influence of wind on heat exchange and body temperature regulation in Jersey, Holstein, Brown Swiss and Brahman cattle. Missouri: Missouri Agricultural Experiment Station Research, 1954. 39p. (Bulletim, 552).

KOBAYASHI, K.; SALAM, M. Comparing simulated and measured values using mean squared deviation and its components. Agronomy Journal, v.92, p.345-352, 2000.

LITTELL, R.C.; FREUND, R.J.; SPECTOR, P.C. SAS ${ }^{\circledR}$ System for linear models. 3.ed. Cary: SAS Institute, 1991. 329p.

MAIA, A.S.C.; DaSILVA, R.G.; LOUREIRO, C.M.B. Sensible and latent heat loss fluxfrom the body surface of Holstein cows in a tropical environment. International Journal of Biometeorology, v.50, n.1, p.17-22, 2005 a.

MAIA, A.S.C.; DaSILVA, R.G.; LOUREIRO, C.M.B. Respiratory heat loss flux of Holstein cows in a tropical environment. International Journal of Biometeorology, v.49, n.5, p.332336, 2005 b.

MAIA, A.S.C. Transferência de calor latente e sensível em vacas Holandesas manejadas em ambiente tropical. Jaboticabal: Universidade Estadual Paulistas, 2005. 94p. Tese (Doutorado em Zootecnia) - Universidade Estadual Paulista, 2005. 
MCGOVERN, R.R.; BRUCE, J.M. A model of the thermal balance for cattle in hot conditions. Journal Agricultural Engineer Research, v.77, p.81-92, 2000.

McLEAN, J.A.; STOMBANGH, D.P.; DOWNIE, A.J. Body heat storage in steers (Bostaurus) in fluctuating thermal environments. Journal of Agricultural Science, v.100, p.315-322, 1983.

MCLEAN, J.A. The partition of insensible losses of body weight and heat from cattle under various climatic conditions. Journal of Physiology, v.167, p.427-447, 1963.

STATISTICAL ANALYSES SYSTEM - SAS. SAS user's guide: statistics. Cary: SAS Institute, 2001. 956p.

STEVENS, D.G. A model of respiratory vapor loss in Holstein dairy cattle. Transactions of the ASAE, v.24, p.151-158, 1981.

TURNPENNY, J.R.; MCARTHUR, A.J.; CLARK, J.A. et al. Thermal balance of livestock. 1. A parsimonious model. Agricultural Forest Meteorology, v.101, p.15-27, 2000. 